11-IEAV-0028

\title{
INDEPENDENT VERIFICATION REVIEW AND SURVEY OF THE ARGONNE NATIONAL LABORATORY BUILDING 301 FOOTPRINT ARGONNE, ILLINOIS
}

\author{
E.N. BAILEY
}

This document was produced under contract number DE-AC05-06OR23100 between the U.S. Department of Energy and Oak Ridge Associated Universities.

Oak Ridge Associated Universities (ORAU) is a university consortium leveraging the scientific strength of major research institutions to advance science and education by partnering with national laboratories, government agencies, and private industry. ORAU manages the Oak Ridge Institute for Science and Education for the U.S. Department of Energy.

\section{OR I S E}

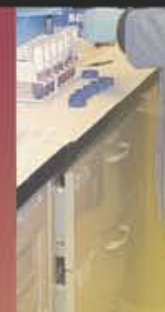

Oak Ridge Institute for Science and Education

Approved for public release; further dissemination unlimited. 


\title{
INDEPENDENT VERIFICATION REVIEW AND SURVEY OF THE ARGONNE NATIONAL LABORATORY BUILDING 301 FOOTPRINT ARGONNE, ILLINOIS
}

\author{
Prepared by \\ E. N. Bailey

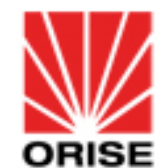

Prepared for the

U.S. Department of Energy

FINAL REPORT

May 2010

This report is based on work performed by the Oak Ridge Institute for Science and Education under contract number DE-AC05-06OR23100 with the Department of Energy. 


\title{
ACKNOWLEDGMENTS
}

The author would like to acknowledge the significant contributions of the following staff members:

\section{FIELD STAFF}

\author{
T. M. Piquet
}

\section{LABORATORY STAFF}

R. D. Condra

W. P. Ivey

\section{CLERICAL STAFF}

J. L. Clary

R. M. Fink

K. M. Moore

A. Ramsey

\section{ILLUSTRATOR}

\author{
A.M. Hood \\ J. A. Viars
}




\section{TABLE OF CONTENTS}

\section{PAGE}

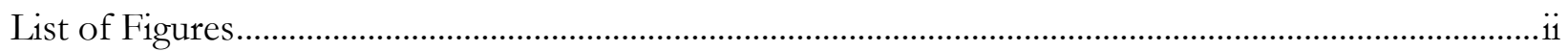

Abbreviations and Acronyms..........................................................................................................iii

Introduction and Site History …………………………………………………………………..



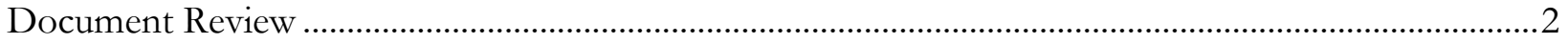

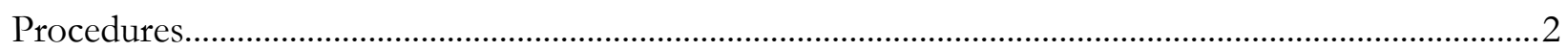

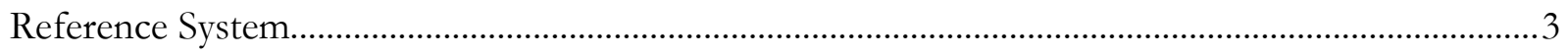

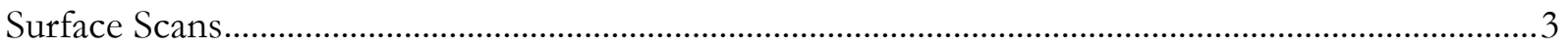

Applicable Site Guidelines................................................................................................................

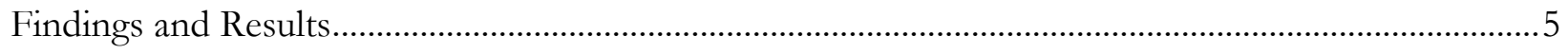

Document Review..........................................................................................................

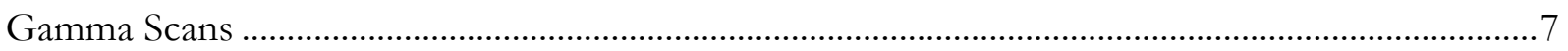

Summary

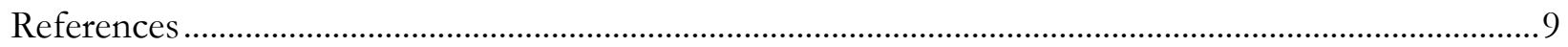

Appendices:

Appendix A: Figures

Appendix B: Major Instrumentation

Appendix C: Survey and Analytical Procedures 


\section{LIST OF FIGURES}

PAGE

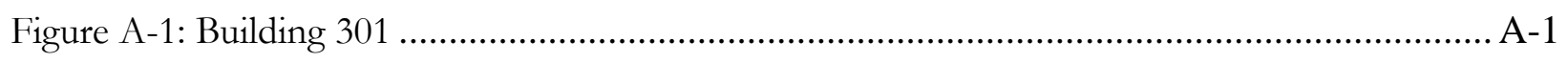

Figure A-2: FIDLER Results in Building 301 Footprint ..................................................... A-2

Figure A-3: NaI (Fluke) Results in Building 301 Footprint .................................................... A-3

Figure A-4: NaI (Fluke) Gamma Scan Count Rate Histogram ................................................. A-4

Figure A-5: FIDLER Gamma Scan Count Rate Histogram .................................................. A-4 


\section{ABBREVIATIONS AND ACRONYMS}

$\begin{array}{ll}\text { ANL } & \text { Argonne National Laboratory } \\ \text { cpm } & \text { counts per minute } \\ \text { DOE } & \text { Department of Energy } \\ \text { FIDLER } & \text { field instrument for the detection of low energy radiation } \\ \text { FSS } & \text { final status survey } \\ \text { GPS } & \text { Global Positioning System } \\ \text { ICP-MS } & \text { inductively coupled plasma mass spectroscopy } \\ \text { IEAV } & \text { Independent Environmental Assessment and Verification } \\ \text { LCS } & \text { laboratory control sample } \\ \text { MACE } & \text { Melt Attack and Coolability Experiments } \\ \text { MARSSIM } & \text { Multi-Agency Radiation Survey and Site Investigation Manual } \\ \text { MDC } & \text { minimum detectable concentration } \\ \text { NaI } & \text { sodium iodide } \\ \text { NRC } & \text { Nuclear Regulatory Commission } \\ \text { ORAU } & \text { Oak Ridge Associated Universities } \\ \text { ORISE } & \text { Oak Ridge Institute for Science and Education } \\ \text { QC } & \text { quality control } \\ \text { R/hr } & \text { roentgen/hour } \\ \text { RPD } & \text { relative percent difference } \\ \text { TPU } & \text { total propagated uncertainty }\end{array}$




\section{INDEPENDENT VERIFICATION REVIEW AND SURVEY OF THE ARGONNE NATIONAL LABORATORY BUILDING 301 FOOTPRINT ARGONNE, ILLINOIS}

\section{INTRODUCTION AND SITE HISTORY}

Argonne National Laboratory (ANL) is a direct descendant of the University of Chicago's Metallurgical Laboratory, part of the World War II Manhattan Project. Building 301, referred to as the Hot Cell Facility, was one of the first buildings occupied at the "new" ANL site. Facility drawings for the building date back to 1951 although little or no documentation has been found describing the actual work performed in the building. The available working history summarized below was compiled through interviews with current and retired ANL employees.

During the 1950s, research and development of nuclear reactor fuel materials and components was conducted. Large amounts of plutonium $(\mathrm{Pu})$ and uranium $(\mathrm{U})$ were handled and processed which resulted in frequent high levels of loose and airborne contamination. Work within the building intensified during the 1960 s and the amount of contamination increased significantly. Anecdotal evidence suggests that there were a number of significant spill incidents. Spills specifically mentioned were a 5 -gallon container of $\mathrm{U}$ in an acid solution reading 100 roentgen/hour $(\mathrm{R} / \mathrm{hr})$, loose Cs-137 in the kilocurie range of activity, and clouds of Pu-bearing dust. In 1974, paint was applied to the floors and walls to fix contamination in place. Work performed in the building after this time still involved some use of radioactive materials including the Melt Attack and Coolability Experiments (MACE) with U-oxide mixtures. In 1992, a MACE setup exploded blowing out a window and moving the cell door off its track. Active work was discontinued in the Hot Cell portion of the building after 1992 (ANL 1998).

Argonne National Laboratory is located in the city of Lemont, Illinois approximately 25 miles southwest of Chicago. ANL occupies 1,500 wooded acres and the land area surrounding the site consists of residential, commercial, and industrial properties. Building 301 has been torn down and demolition included removal of the foundation and all contaminated soil in the general vicinity of building footprint. Building 301 was approximately 14,000 gross square feet, so the area of the final excavation was larger. The Building 301 footprint is located near the intersection of Meridian and Rock Roads. Buildings 302 and 303 are adjacent to the footprint and are still in use to date. 
The U.S. Department of Energy (DOE) is responsible for oversight of the remedial action and final status survey (FSS) activities of the Building 301 footprint. It is the policy of the DOE to perform independent (third party) verification of FSS activities (DOE 2006). The Independent Environmental Assessment and Verification (IEAV) Program of the Oak Ridge Institute for Science and Education (ORISE) was designated by the DOE as the Independent Verification Contractor responsible for this task and was requested to verify the final radiological status of the cleanup activities associated with the Building 301 footprint area.

\section{OBJECTIVES}

The objectives of the verification activities were to provide independent document and field data reviews in evaluating the adequacy and accuracy of the contractor's procedures and FSS results. The onsite verification survey was performed in order to generate independent radiological scan data and sample data (if necessary) for use by the DOE to verify that remedial actions were effective in reaching background levels.

\section{DOCUMENT REVIEW}

The first phase of the independent verification process was to obtain and review the contractor's Building 301 footprint FSS Plan and procedures for adequacy and appropriateness taking into account any supporting documentation and Multi-Agency Radiation Survey and Site Investigation Manual (MARSSIM) guidance (NRC 2000). The purpose of the review was to ensure that the FSS

plan was designed appropriately to meet the soil cleanup objectives. ORISE also requested to receive all the FSS data, including scan data and analytical results, for the footprint area prior to any onsite activities.

\section{PROCEDURES}

A survey team from ORISE visited the Building 301 footprint to perform visual inspections and measurement and sampling activities on September 14, 2009. The survey activities were conducted in accordance with a DOE approved site-specific verification survey plan and the ORISE/IEAV Survey Procedures and Quality Program Manuals (ORISE 2009, 2008, and ORAU 2009). 


\section{REFERENCE SYSTEM}

Global positioning system (GPS) coordinates were used for referencing gamma scan measurement locations. The specific coordinate reference system used for the survey was: North American Datum 1983 State Plane Illinois East FIPS 1201 Feet.

\section{SURFACE SCANS}

Medium-density surface scans for gamma radiation were conducted within all accessible areas associated with the Building 301 footprint FSS activities. There were areas with standing water as well as excavation sidewalls with steep slopes that were inaccessible. Scans were performed using both Fluke sodium iodide $(\mathrm{NaI})$ and Field Instrument for the Detection of Low Energy Radiation (FIDLER) detectors coupled to ratemeter-scalers with audible indicators that were coupled to Trimble GeoXH GPS/dataloggers with sensor input that enables real-time gamma count rate and position data capture. ORISE field personnel relied on the audio output to identify any locations of elevated direct gamma radiation that might suggest the presence of residual contamination.

\section{APPLICABLE SITE GUIDELINES}

The primary contaminants of concern for the Building 301 footprint are beta-gamma emitters and fission and activation products resulting from research and development activities. Alpha contamination, specifically $\mathrm{Pu}-239$, has also been identified. Soil cleanup criteria were developed for the significant radionuclide contributors listed in the table below (DEMCO 2009). These are upper background limit values based on analyses performed on samples collected from locations of sufficient distance from ANL such that they are considered unaffected by Argonne operations (ANL 2008). 
APPLICABLE RADIOLOGICAL SOIL CLEANUP CRITERIA

\begin{tabular}{|c|c||}
\hline Radionuclide & Concentration (pCi/g) \\
\hline \hline Hydrogen-3 (Tritium) & 0.04 \\
\hline Potassium-40 & 25.2 \\
\hline Strontium-90 & 0.2 \\
\hline Cesium-137 & 1.0 \\
\hline $\begin{array}{c}\text { Other Gamma-Ray Emitting Fission } \\
\text { and Activation Products }\end{array}$ & 0.2 \\
\hline Uranium & 1.73 \\
\hline Uranium Daughters & 1.73 \\
\hline Thorium & 1.76 \\
\hline Thorium Daughters & 1.76 \\
\hline Plutonium-239 & 0.03 \\
\hline Americium-241 & 0.01 \\
\hline
\end{tabular}

One concern that ORISE made note of prior to onsite verification activities was the very low cleanup criteria concentrations for some of the radionuclides. The typical Minimum Detectable Concentrations (MDCs) that the ORISE Laboratory is able to report are indicated below. Of specific concern are tritium, Sr-90, and Am-241. Lower MDCs can be reached with additional effort (i.e. much longer counting times, etc.). However, even if the ORISE laboratory were to count a sample for tritium for a week, the resulting MDC $(0.3-0.6 \mathrm{pCi} / \mathrm{g})$ would still not be below the cleanup criteria. 
TYPICAL MINIMUM DETECTABLE CONCENTRATIONS THE

ORISE LABORATORY REPORTS

\begin{tabular}{|c|c|}
\hline Radionuclide & $\mathrm{MDC}(\mathrm{pCi} / \mathrm{g})$ \\
\hline Hydrogen-3 (Tritium) & 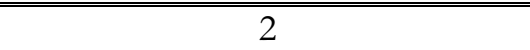 \\
\hline Potassium-40 & 0.05 \\
\hline Strontium-90 & 0.4 \\
\hline Cesium-137 & 0.1 \\
\hline $\begin{array}{l}\text { Other Gamma-Ray Emitting Fission } \\
\text { and Activation Products }\end{array}$ & $\begin{array}{c}\text { Co-60 (0.1); Cs-134 (0.1) } \\
\text { Mn-54 (0.1) }\end{array}$ \\
\hline Uranium & $\begin{array}{c}\text { U-235 and U-236 (0.02-0.03); } \\
\text { U-238 (1.2) }\end{array}$ \\
\hline Uranium Daughters & $\begin{array}{c}\text { Pb-214 and Bi-214 (0.2); } \\
\text { Th-230 (20) }\end{array}$ \\
\hline Thorium & Th-232 from Ac-228 (0.2); \\
\hline Thorium Daughters & Th-228 from Pb-212 (0.1) \\
\hline Plutonium & $\begin{array}{c}\mathrm{Pu}-239(0.02-0.05) \\
\mathrm{Pu}-238 \text { and } \mathrm{Pu}-240(0.02-0.04)\end{array}$ \\
\hline Americium-241 & $0.02-0.05$ \\
\hline Europium & Eu-154 (0.05 - 0.10) Eu-155 (0.10) \\
\hline
\end{tabular}

\section{FINDINGS AND RESULTS}

\section{DOCUMENT REVIEW}

The only FSS "Plan" that ORISE received was drafted prior to building demolition and was a basic document that outlined the intent to later generate a FSS plan (DEMCO 2009). However, ORISE never received the FSS plan for the Building 301 footprint area post building demolition although multiple inquiries and requests were made. Prior to the onsite survey activities, ORISE received an analytical results package to review but it only contained results for samples collected during characterization. Additionally, the analyses were performed by the ANL Analytical Chemistry Division which did not perform the FSS soil sample analyses. Furthermore, there were only analyses for one soil sample contained in the ANL submittal for ORISE to review (ANL 2006). An ORISE Radiochemist conducted the review and had numerous technical issues of note including the following:

- Acid leaching that was not total or consistent for the samples.

- There was no separation of elements for the alpha analysis (i.e. no isotopic separation/distinction in peaks; therefore, the reported results only provided gross alpha 
information at best). Furthermore, they performed a total alpha scan by alpha spectroscopy but there is no way to conclude that these isotopes are what they claimed as other peaks could interfere. Additionally, they did not report a total propagated uncertainty (TPU).

- For the Inductively coupled plasma mass spectroscopy (ICP-MS) analyses, they estimated a TPU of $10 \%$ but there was no explanation as to why. Additionally, the ICP-MS data was reported as semi-quantitative only. Then the semi-quantitative $\mathrm{U}-238$ value determined by ICP-MS was used to evaluate the alpha emitters by alpha scan. Therefore, the alpha results they reported were based on an originally semi-quantitative value.

While onsite for verification activities, ORISE requested to receive FSS data again to review and specifically for the data to include surface scan data and analytical results. However, on September 15, 2009 ORISE only received a partial analytical package for 30 FSS soil samples to review (TEST 2009). An offsite laboratory, TestAmerica Laboratories, Inc., performed these analyses. The same ORISE Radiochemist performed a review of the analytical package and noted the following:

- Quality Control requirement for the relative percent difference (RPD) on their duplicate sample was not stated. However, on the last page of the submittal, the duplicate for iso- $U$ for sample \#1, the reported RPD for U-234 is 64\% and for U-238 is 37\%. Two possible issues exist. First the RPD is very high (especially the 64\%) for natural uranium in soil. This could be caused by inhomogeneity in the sample, but for natural $\mathrm{U}$, this is considered high. Second, even if the sample is inhomogeneous, a more similar RPD for both U-234 and U-238 would be expected. That is either both would be expected to be close to $64 \%$ or both close to $37 \%$, (the RPD of the RPD is $54 \%$ which means that their duplication for the two U isotopes is not in agreement.

- The biggest issue identified was related to the laboratory control sample (LCS) data for uranium. The recovery of both U-234 and U-238 are very low. For example, the ORISE acceptable range for LCS (in the same units) is $80-120 \%$. TestAmerica reported $65 \%$ and $58 \%$ recovery for $\mathrm{U}-234$ and $\mathrm{U}-238$, respectively. Additionally, the lower control limit is reported as 68\% and 67\% for U-234 and U-238, respectively. This indicates that they did not even pass their own quality control requirements for this batch, thus the batch should have been either qualified or scrapped and re-run. 
This information was provided to DOE following the ORISE review on September 16, 2009. In a follow-up review of the same analytical package, the ORISE Laboratory Manager also noted that Th-234, which is the first daughter of $\mathrm{U}-238$, was identified by gamma spectroscopy in seven of the first 10 samples (a batch). However, no uranium isotopes were identified by alpha spectroscopy. For natural uranium in soil samples, the Th-234 and U-238 activities should be statistically equal. The review of the uranium isotopic batch data report for samples one through 10 attached at the end of the package showed that U-234 and U-238 were clearly identified as statistically positive above the MDC indicating there was an inconsistency in their data reporting process. Also, there was no batch blank data provided and the Quality Control (QC) data were incomplete.

On September 16, 2009, ORISE was informed that TestAmerica was going to reanalyze the samples based on the ORISE findings; however, DOE authorized the contractor to proceed with backfill of the area based on an Argonne Health Physicist's and the ANL Environmental Safety and Health Department's approval. The analytical report for reanalysis of the samples was not provided to ORISE until November 2, 2009. The ORISE Laboratory Manager still performed a review of the analytical report and concluded that all the required QC items were included, the uranium isotopic data was comparable between the data sets, and the results were acceptable for the samples that were reanalyzed.

\section{GAMMA SCANS}

Prior to backfilling the area, gamma scans of the accessible excavation area were performed using both FIDLER and Fluke NaI detectors. No locations of elevated gamma radiation were identified. Scans ranged from 600 to 1,300 counts per minute (cpm) with the FIDLER detector and 400 to 3,700 cpm with the Fluke NaI detector. Scan results are illustrated in Figures A-2 and A-3. Histograms of the gamma count rate distributions are provided in Figures A-4 and A-5. ORISE did not identify any locations of elevated radiation levels exceeding twice background for the area; therefore, no soil samples were collected for analysis. ORISE and DOE agreed that ORISE's review of the contractor's FSS data and analytical laboratory reports would be sufficient. 


\section{SUMMARY}

ORISE performed onsite verification survey activities of the Building 301 footprint area at ANL on September 14, 2009. The onsite activities included collecting independent gamma scan measurements. The survey results did not identify any locations of elevated radiation levels exceeding twice background within the footprint area. Following onsite activities, ORISE was provided a partial FSS laboratory data package to review. Upon identifying several technical issues with the analyses and reporting, ORISE was informed that those FSS samples were being re-analyzed; however, DOE approved the backfill of the area on September 16, 2009 prior to receiving the re-analyzed results. The subsequent laboratory report for the samples that were re-analyzed was provided to ORISE on November 2, 2009 and although the Building 301 footprint area was already backfilled, the review determined the analytical results were acceptable. 


\section{REFERENCES}

Argonne National Laboratory (ANL). Characterization Report for Building 301 Hot Cell Facility (ANL/ESH-HP-98/02). Argonne, Illinois; 1998 (exact date not listed).

ANL 1999. Building 301 Phase II Characterization Survey Supplemental Report. Argonne, Illinois; April 20.

ANL 2006. Analytical Chemistry Laboratory Report of Analytical Results, Building 301 D\&D Samples SDG: P-C102-F-001. Argonne, Illinois; March 14.

ANL 2008. Environment, Safety and Health Manual. Argonne, Illinois; March 13.

Decommissioning \& Environmental Management Company (DEMCO). Final Status Survey Plan-Building 301 Hot Cell Facility Demolition Project (589-ANL-03). Lemont, Illinois; June 19, 2009.

Oak Ridge Associated Universities (ORAU). ORAU/ORISE Health \& Safety Manual. Revision 12. Oak Ridge, TN; April 2, 2008.

ORAU 2005. ORAU/ORISE Radiation Protection Manual. Oak Ridge, TN; September 10.

ORAU 2009. Quality Program Manual for the Independent Environmental Assessment and Verification Program. Oak Ridge, TN, June 30.

http://orise.orau.gov/ieav/survey-projects/pubs/qpmanual.pdf.

Oak Ridge Institute for Science and Education (ORISE). Survey Procedures Manual for the Independent Environmental Assessment and Verification Program. Oak Ridge, TN; May 1, 2008. http:/ / orise.orau.gov/ieav/survey-projects/pubs/survey-manual/full-survey-manual.pdf.

ORISE 2009. Final Project-Specific Plan for the Independent Verification Review and Survey of the Argonne National Laboratory Building 301 Footprint, Argonne, Illinois. DCN 5061-PL-01-0. Oak Ridge, TN, September 11.

U.S. Department of Energy (DOE). Environment, Safety and Health Bulletin: A Guide to Good Practices for the Control and Release of Property. DOE/EH-0697. Washington, DC. July 2006.

U.S. Nuclear Regulatory Commission (NRC). Multi-Agency Radiation Survey and Site Investigation Manual (MARSSIM), NUREG-1575; Revision 1. Washington, DC; August 2000. 
APPENDIX A

FIGURES 


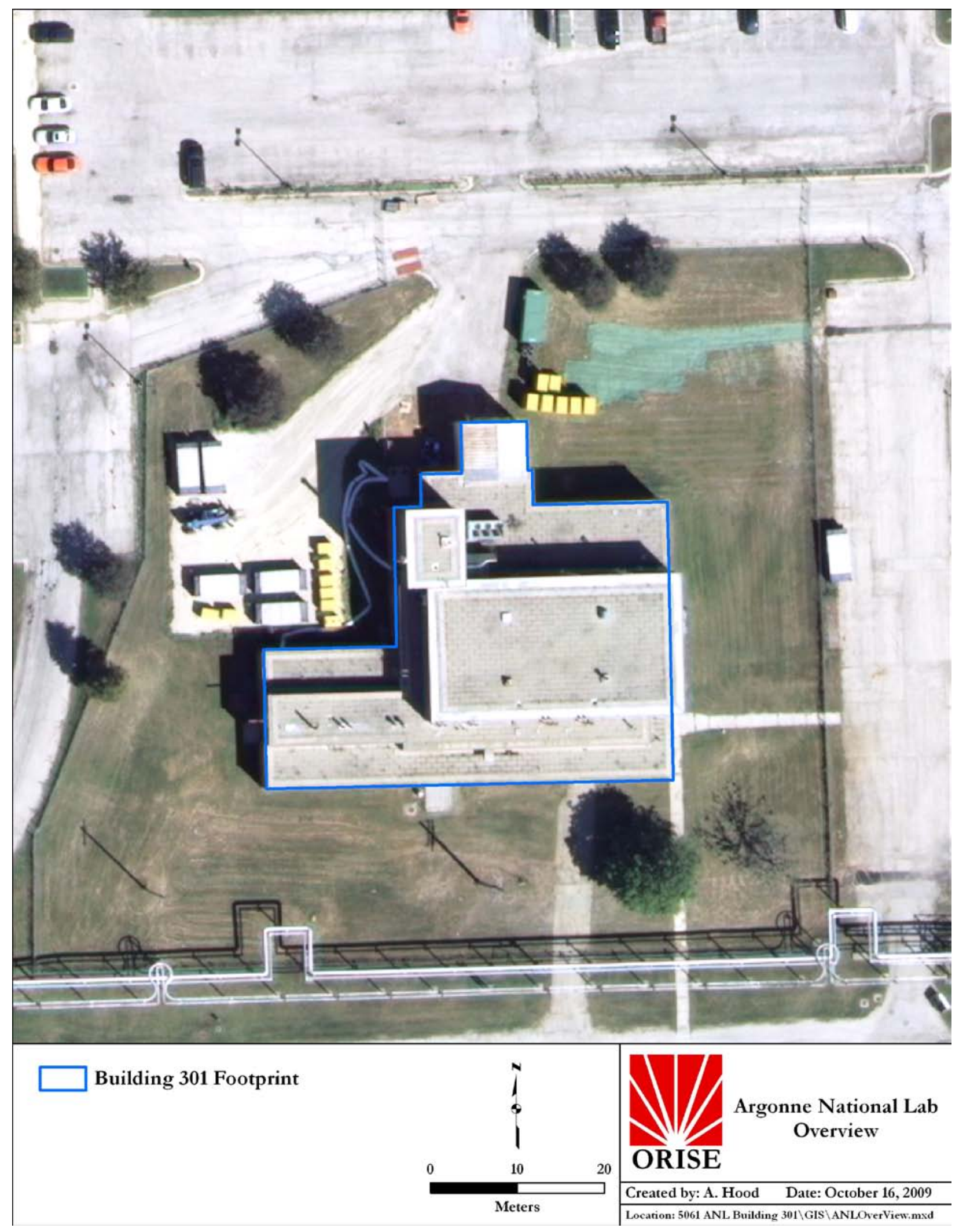

Figure A-1: Building 301 


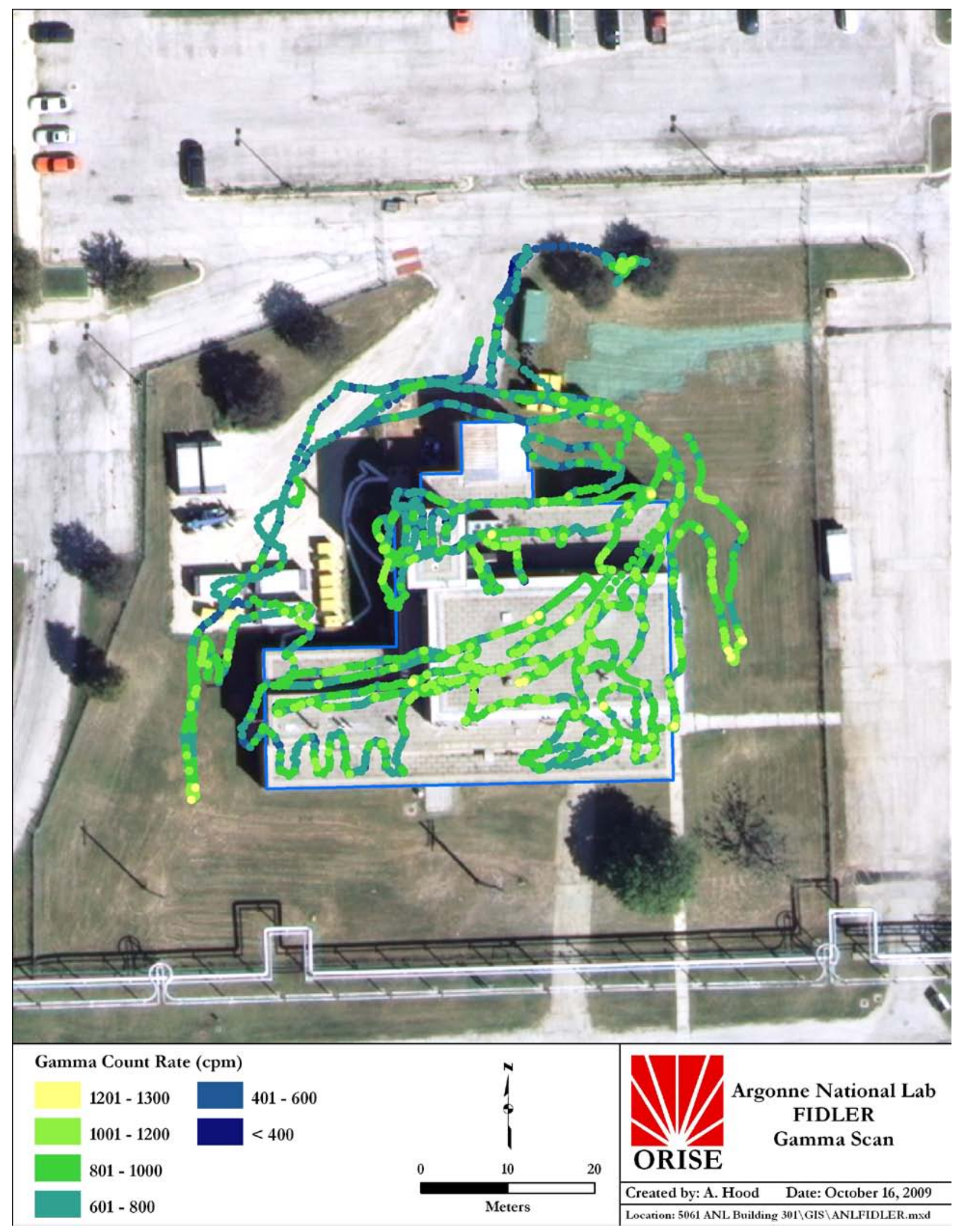

Figure A-2: FIDLER Results in Building 301 Footprint 




Figure A-3: NaI (Fluke) Results in Building 301 Footprint 


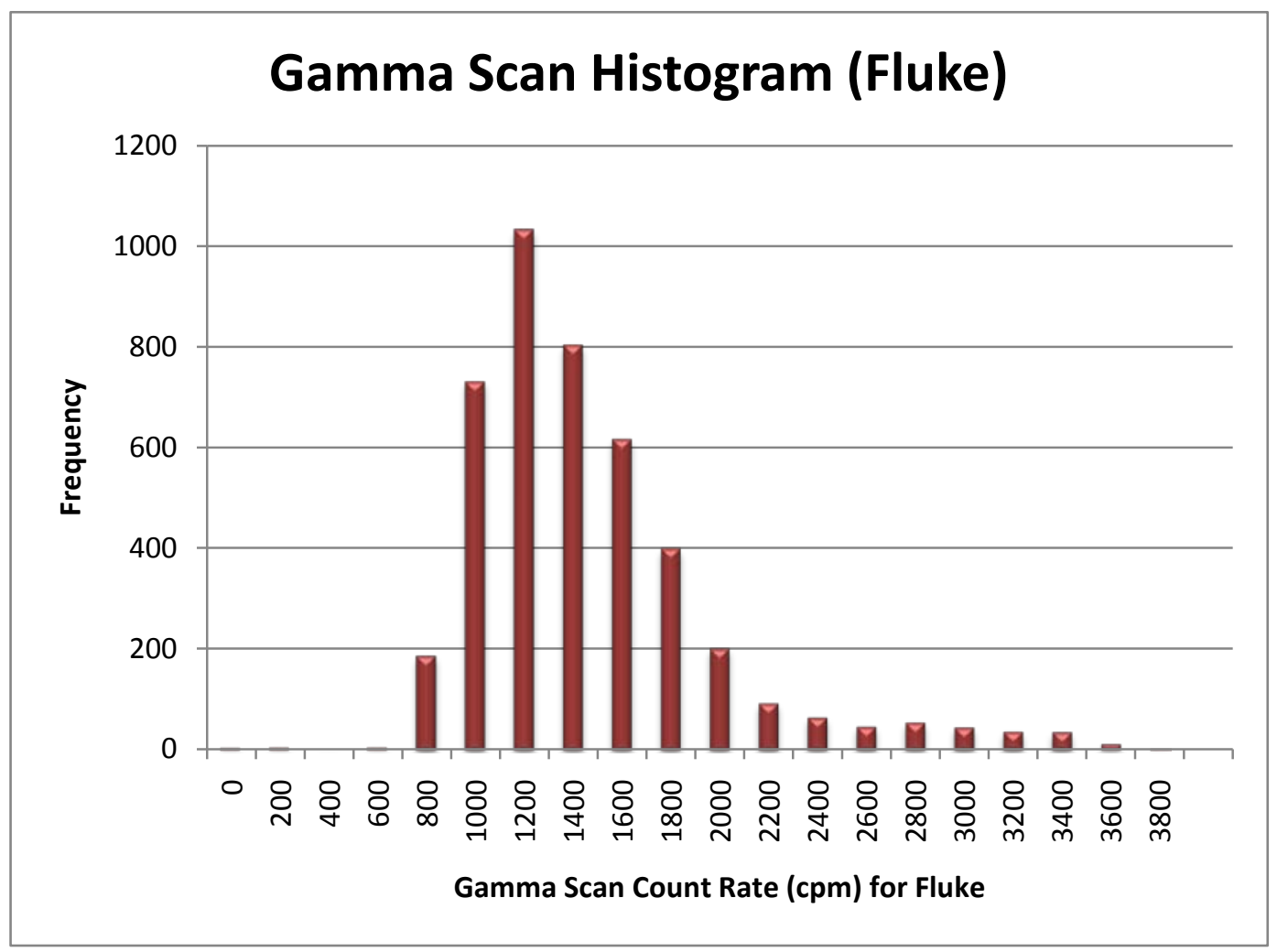

Figure A-4: NaI (Fluke) Gamma Scan Count Rate Histogram

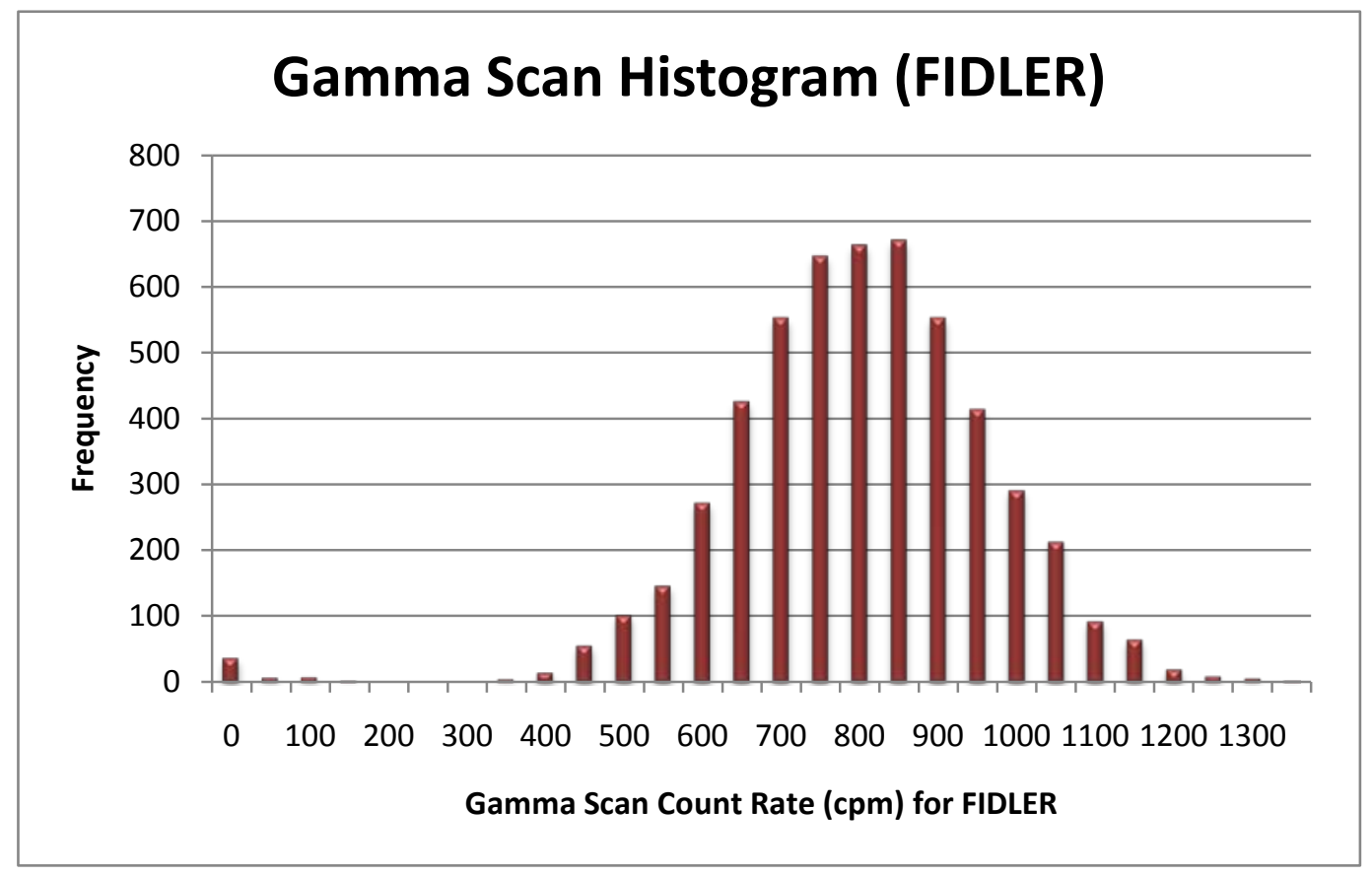

Figure A-5: FIDLER Gamma Scan Count Rate Histogram 
APPENDIX B

MAJOR INSTRUMENTATION 


\section{APPENDIX B}

\section{MAJOR INSTRUMENTATION}

The display of a specific product is not to be construed as an endorsement of the product or its manufacturer by the author or her employer.

\section{SCANNING INSTRUMENT/DETECTOR COMBINATIONS}

\section{$\underline{\text { Gamma }}$}

Ludlum Ratemeter-Scaler Model 2221

coupled to

Fluke NaI Scintillation Detector Model 489-55, Crystal: $3.8 \mathrm{~cm}$ x $3.8 \mathrm{~cm}$

(Fluke Biomedical, Cleveland, $\mathrm{OH}$ )

coupled to

Trimble GeoXH Receiver and Data Logger (Trimble Navigation Limited, Sunnyvale, CA)

Ludlum Ratemeter-Scaler Model 2221

coupled to

Bicron Field Instrument Detector for Low Energy Radiation (FIDLER) Model G5

(Bicron Corporation, Newburg, $\mathrm{OH}$ )

coupled to

Trimble GeoXH Receiver and Data Logger (Trimble Navigation Limited, Sunnyvale, CA) 
APPENDIX C

SURVEY AND ANALYTICAL PROCEDURES 


\section{APPENDIX C}

\section{SURVEY AND ANALYTICAL PROCEDURES}

\section{Project Health AND SAFETy}

The survey and sampling procedures were evaluated to ensure that any hazards inherent to the procedures themselves were addressed in current job hazard analyses. Prior to onsite activities, a pre-job integrated safety management checklist was completed and discussed with field personnel. Additionally, upon arrival at the site, representatives from ANL provided site-specific safety awareness training. ORISE was also briefed on the potential health and safety issues for the footprint area. Verification surveys activities were conducted in accordance with the ORISE health and safety and radiation protection procedures (ORAU 2008 and 2005).

\section{Calibration AND Quality Assurance}

Calibration of all field and laboratory instrumentation was based on standards/sources, traceable to National Institute of Standards and Technology.

Analytical and field survey activities were conducted in accordance with procedures from the following documents of the Independent Environmental Assessment and Verification Program:

- $\quad$ Survey Procedures Manual (ORISE 2008)

- Quality Program Manual (ORAU 2009)

The procedures contained in these manuals were developed to meet the requirements of DOE Order 414.1C and the U.S. Nuclear Regulatory Commission Quality Assurance Manual for the Office of Nuclear Material Safety and Safeguards and contain measures to assess processes during their performance.

Quality control procedures include:

- Daily instrument background and check-source measurements to confirm that equipment operation is within acceptable statistical fluctuations.

- $\quad$ Training and certification of all individuals performing procedures.

- $\quad$ Periodic internal and external audits 


\section{SuRVEy Procedures}

\section{$\underline{\text { Surface Scans }}$}

Scans for elevated gamma radiation were performed by passing the detector slowly over the surface. The distance between the detector and surface was maintained at a nominal of about 1 to $5 \mathrm{~cm}$. A Fluke NaI scintillation detector and a low-energy photon FIDLER detector (detector area $127 \mathrm{~cm}^{2}$ ) were coupled to GPS units that enabled real-time recording of position in one-second intervals.

Specific scan MDCs for the detectors were not determined as the instruments were used solely as a qualitative means to identify elevated gamma radiation levels in excess of background. The identification of elevated radiation levels that could exceed the site criteria are determined based on an increase in the audible signal from the indicating instrument. 